\title{
Effect of Head Types on the Free Vibration and Fatigue for Horizontal LPG Pressure Vessels
}

\author{
Marwan Abdulrazzaq Salman \\ Mechanical Eng. Dep. \\ Al-Nahrain University, Baghdad, IRAQ \\ mwaf_1989@yahoo.com
}

Received: 03-June-2018

http://doi.org/10.29194/NJES.21040494

\author{
Mahmud Rasheed Ismail \\ Prosthetics and orthotics Eng. Dept. \\ Al-Nahrain University, Baghdad, IRAQ \\ mahmech2001@yahoo.com_yassrykahtan@eng.nahrainuniv.edu.iq
}

Revised: 03-July-2018 Accepted: 18-Sep.-2018

\begin{abstract}
Pressure vessels are the heart of plants and oil refineries stations. In many engineering applications such vessels can be subjected to periodic loading either internally due to the charging and discharging process or externally due to the excitation from other nearby components such as pumps, compressors or from seismic. So that in spite of a good design according static assumption it may be critical in dynamics. In this work a horizontal pressure vessel with accessories subjected to liquefied petroleum gas pressure LPG is considered. Three models of different head types are investigated herein namely; Deep torispherical, Elliptical 2:1 and Hemispherical. The design and material selections are chosen as per ASME. For practical service many accessories are attached to the vessel such as manhole, supports, inlet and outlet opining. Finite Element method via ANSYS R18.2 is introduced for the numerical analysis. The fatigue life in case of fully reversed cyclic loading are estimated and located. Vibration characteristics such as mode shapes and natural frequencies for the lowest five modes are evaluated and compared. It is found that the fatigue life can be increased as higher as $180 \%$ for hemi- spherical head as compared with deep torispherical head pressure vessel and the lowest four natural frequencies are nearly identical for all models, however significant change observed in the fifth natural frequency.
\end{abstract}

Keywords: Pressure Vessel, ASME codes, Finite Element Analysis, Stress, Deformation.

\section{Introduction}

Pressure vessel are the core components in many plants and oil refineries plants. These vessels can be classified in different manners according to shape, supporting type, operation, materials and function. In this regards the pressure vessel can be classified as spherical or cylindrical, vertical or horizontal, low, moderate or high pressure, gas, LPG or liquid, above or submerge, on ground, on truck or on ship and so on. The wide verity of classifications reflect the wide practical applications of these vessels.

ASME codes are the most practical criteria used for designing and testing of pressure vessels and its accessories. Due to the variety in pressure vessels which are ranged from nuclear vessels to fuel tanks. ASME codes prefers three divisions to include all these types. Division I for low pressure, division II for moderate pressure and division III for high pressure (greater than $10,000 \mathrm{psi}$ ). Many researchers investigated the behavior of pressure vessels. In this regard B.S.Thakkar, 2S.A.Thakkar (2013) [1] investigated the high pressure rise in the pressure vessel. Hydrostatic tests were carried out to test the vessel at different pressures. ASME criteria was employed to design and manufacture the pressure vessel. Niyamat, M., \& Bicha, K. (2015) [2] considered two types of stresses, due to the effect of the internal pressure and thermal stress due to loading when handling a hot fluid. In this paper the stresses are calculated using ANSYS with coupled field analysis for thermo-mechanical loading. The results are compared with analytical solution. They concluded that; analytical solutions such as ASME and Japanese Code give empirical relationships to calculate thermal stress. And using of FEA technique is very popular in pressure vessel design. Manish M. et al 2013 [3] studied the effect of stresses at the opening in the pressure vessel assuming round shape. Aluminum alloy is used for construction the vessel wall under the effect of internal pressure. Finite element method is used for analyzing stresses. A comparison between experiments and numerical analysis were made under the effects of many parameters related to the operation conditions. Dhanaraj, A., and Mallikarjuna, M. V. (2015) [4] investigated the effect of static loading on the behavior of pressure vessel. Finite element analysis via ANSYSI program is used for the numerical analysis. The main objectives of this work is to investigate the effect of fluctuating load. Manufacturing methods for industries applications were suggested to suit different requirements in service. Kumar, V., \& Kumar, P. (2014) [5] studied the effect of material properties such as safety factor for tensile and yield strength on the vessel design and operation. ASME section VIII is employed in design and testing, PV ELITE software is used in the theoretical analysis of horizontal pressure vessel containing opening and saddle supports The main factors investigated in this research are; effect of internal and external pressure, geometry and weight, nozzle and saddle design. 
Dubal, S. V., et al. (2014) [6] investigated the effect of high pressure in pressure vessel according to ASME codes namely; division 1 and division 2, section VIII, the effect of stresses were investigated on the design to maintain safe design and operation conditions Narale, P., and Kachare, P. S. (2012) [7] studies the effect of the opening size especially for large opening such as manhole for pressure vessels. ASME Sec. VIII Division 1 was followed in this study. Finite element analysis is used to evaluate the stresses developed at the vessel wall and opening. The stress analysis is performed by ANSYS software. In this work a large exhaust opening located near to the filter sheet are considered. The effect of stresses in the large opening are treated as per ASME to validate the design Sankara et al. (2013) [8] investigated the shape and geometry of a manhole at the upper part of a cylindrical pressure vessel. Two opening types are investigated namely ; circular and elliptical opening. The manhole is locate at the vertical position with respect to the cylindrical vessel. Many aspects related to the manhole walls are considered; such as major axes of the elliptical hole in case of parallel or perpendicularly to the axis of the vessel cylinder. The results were presented in many figures and tables for the design purposes. Kulkarni, A. A., and Jatkar, K. H. (2014). [9] investigated the pressure vessel with varying loads in which the effect of pressure and thickness cylindrical shell is taken as parameters. The study includes the structural analysis and he optimization of pressure vessel to make a theoretical foundation developing the design of pressure vessel. Lewiński, J. (2015) [10] studied the pressure vessels, nozzles required for inlet and outlet attachments. The geometrical parameters of nozzle connections are considered and the effect of a stress concentration around the opening. Also the effect of eccentricity in case of the nozzles are located on the periphery of a pressure vessel. The model is analyzed using Numerical analysis for stress analysis around the nozzle. Tamboli, K. (2014). [11] used fatigue analysis where the effect of thermal stresses and mechanical stresses are included. The research consider the mechanical components on the structural during the design stage. The 2000M3 pressure vessel type is taken as an example to perform the analysis under arbitrary transients condition. The cumulative fatigue factor are evaluated for the safe design. Siva et al. 2013 [12] considered a steel LPG vessel containing fluid with partially liquid and vapor. The stresses due to pressure loading inside the cylinder are investigated. The results of stresses are compared with the available solution in literature to check the theory and the mathematical model. Pro-E WILDFIRE is used to analyze the stresses in the vessel wall. Porter, M., Martens, D., and McGuffie, S. (2006) [13] studied the effect of vibration due to seismic excitation. A numerical solution using FEA was performed to show the response and stresses at the piping and the vessel. The effect of nozzles with pipe attached are included in the design. The main objectives of this work is to minimize the effect of deformation due the seismic and vibration excitations Kumar, V., et al. (2014) [14] analyzed a horizontal vessel with saddle support. A solid model of the pressure vessel with saddle support is employed by using ANSYS software. Then the stresses are obtained from the static analysis. It is found that; the higher localized stress is located at the junction of the pressure vessel and at the saddle support. A comparison between the numerical and theoretical of the allowable stress and safety of design are made in this study. Mukhtar, F. M., and Al-Gahtani, H. J. (2017). [15] considered a cylindrical pressure vessel with nozzle connection according to thin shell stress analysis. The analysis is perfumed numerically by using FE method, In order to validate the analysis the obtained results are compared with other models founded in the literature. It is concluded that; the results for the stresses in the vessels with moderate to large diameter nozzles are larger as compared with that for vessels having small diameter nozzles which is suggested in the research.

As it can be seen from the above review that Finite Element (FM) method is the best suit the analysis of pressure vessels due the complexity of geometry and variety in materials for the attached accessories.

In ASME codes there is no recommendation about choosing of the head type. This is left as an optional to the designer. The main objectives of the present paper is to investigate the effect of using of three head types available for pressure vessels which are; Deep torispherical, Elliptical 2:1 and Hemispherical on fatigue and vibration. Three models are prepared and designed according to ASME codes and analyzed using FE method.

\section{Design Considerations}

Figure 1 shows the geometry, dimension, service accessories and supporting of the horizontal pressure vessel model used in the present analysis. Three different types of head ends are suggested and are shown in fig. 2 . So that three models (1,2 and 3) are treated according to the head type which are presented in table 1 .

Table 2 summarize the main dimensions, operation parameters and materials for the models, Table 3 display the main accessories used in vessel service and table 4 gives the material properties. 


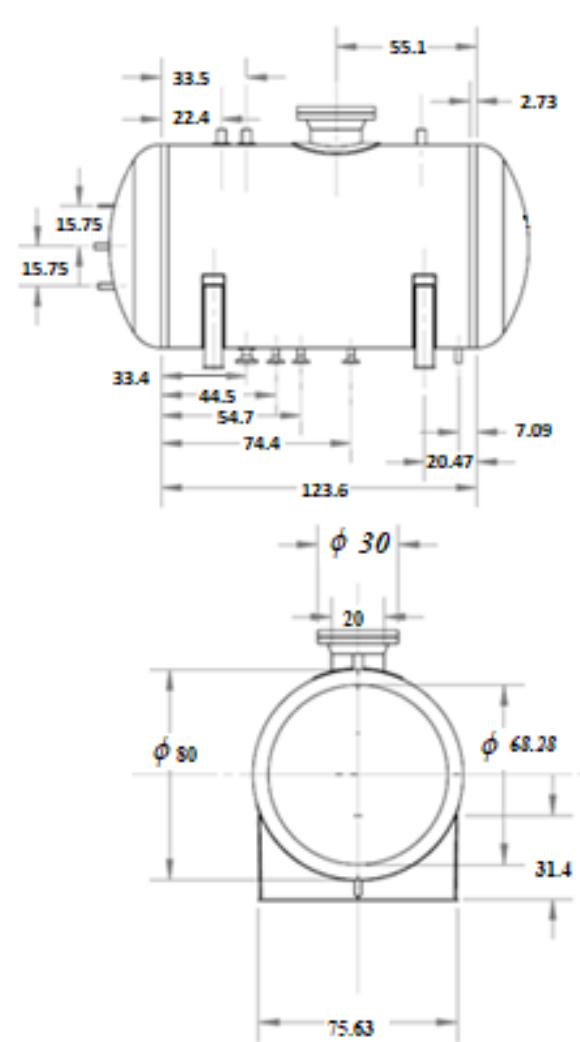

Figure 1: horizontal pressure vessel with accessories

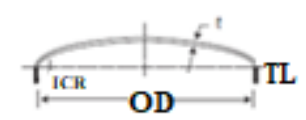

Torisperical head

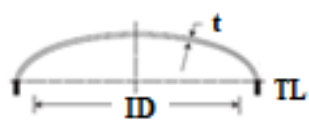

Elliptical head

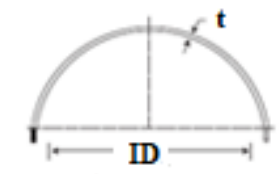

Hemispherical head

Figure 2: Head types [16]

Table 1: Models considered in this study

\begin{tabular}{|c|l|}
\hline Model 1 & $\begin{array}{l}\text { Pressure vessel with Deep } \\
\text { torispherical heads }\end{array}$ \\
\hline Model 2 & $\begin{array}{l}\text { Pressure vessel with Elliptical 2:1 } \\
\text { heads }\end{array}$ \\
\hline Model 3 & $\begin{array}{l}\text { Pressure vessel with Hemi- } \\
\text { spherical heads }\end{array}$ \\
\hline
\end{tabular}

Table 2: Design data of pressure vessel mode

\begin{tabular}{|c|c|}
\hline Diameter & $2000 \mathrm{~mm}$ \\
\hline T-T length & $3140 \mathrm{~mm}$ \\
\hline Content Fluid (S.G) & $\begin{array}{c}\text { LPG } / 0.65 \\
\text { Located } 1329.45 \mathrm{~mm} \\
\text { from c.c }\end{array}$ \\
\hline Design Pressure & $18.0 \mathrm{~kg} / \mathrm{cm}^{2}$ \\
\hline Design Temperature & $-20-70 \mathrm{C}^{\mathrm{o}}$ \\
\hline Corrosion Allowance & $1 \mathrm{~mm}$ \\
\hline Radiography & $\begin{array}{c}\text { (Shell- Spot) (Heads- } \\
\text { Seamless) }\end{array}$ \\
\hline
\end{tabular}

\begin{tabular}{|c|c|}
\hline & (Shell- Heads ) \\
\hline Hydro Test Pressure & $\begin{array}{c}\text { Horizontal POS }(23.5 \\
\left.\mathrm{kg} / \mathrm{cm}^{2}\right)\end{array}$ \\
\hline $\begin{array}{l}\text { Vessel Geometric } \\
\text { capacity }\end{array}$ & $11.0 \mathrm{~m}^{3}$ \\
\hline \multicolumn{2}{|l|}{ Materials } \\
\hline $\begin{array}{c}\text { Shell \& Compensation } \\
\text { Plate }\end{array}$ & A-516 Gr. 70 \\
\hline Heads & A-516 Gr.70 Norm. \\
\hline Pipe, Plate, Ladder, Clips & A-36 \\
\hline Supports (Saddles) & A-283 Gr C \\
\hline $\begin{array}{c}\text { External Branching } \\
\text { Pipe } \\
\text { Flange }\end{array}$ & $\begin{array}{c}\text { A-106 Gr.B } \\
\text { A-105 }\end{array}$ \\
\hline $\begin{array}{c}\text { Internal Branches } \\
\text { Pipe } \\
\text { Flange }\end{array}$ & $\begin{array}{c}\text { A-106 Gr.B } \\
\text { A-105 }\end{array}$ \\
\hline $\begin{array}{l}\text { Manways } \\
\text { Pipe } \\
\text { Flange } \\
\end{array}$ & $\begin{array}{c}\text { A-106 Gr.B } \\
\text { A-105 }\end{array}$ \\
\hline $\begin{array}{c}\text { External Bolting } \\
\text { Nut }\end{array}$ & $\begin{array}{l}\text { A-193 B7 } \\
\text { A-194 2H }\end{array}$ \\
\hline Coupling & A-105 \\
\hline Gasket & CAF \\
\hline
\end{tabular}

Table 3: Vessel nozzles and accessories

\begin{tabular}{|c|c|c|c|c|c|}
\hline \multirow[b]{2}{*}{ Description } & \multirow[b]{2}{*}{ NO. } & \multirow[b]{2}{*}{$\begin{array}{l}\text { DIA. } \\
\text { inch }\end{array}$} & \multicolumn{2}{|c|}{ FLANGE } & \multirow{2}{*}{$\begin{array}{c}\text { SCH. } \\
\text { OR } \\
\text { THK }\end{array}$} \\
\hline & & & TYPE & $\begin{array}{c}\text { RATG } \\
\#\end{array}$ & \\
\hline LIQUID INLET & 1 & 2 & W.N.R.F & 300 & 160 \\
\hline $\begin{array}{l}\text { LIQUID } \\
\text { OUTLET }\end{array}$ & 1 & 3 & W.N.R.F & 300 & 160 \\
\hline $\begin{array}{l}\text { VAPOUR } \\
\text { INLET }\end{array}$ & 1 & 2 & W.N.R.F & 300 & 160 \\
\hline $\begin{array}{l}\text { LIQUID } \\
\text { RETURN }\end{array}$ & 1 & 2 & W.N.R.F & 300 & 160 \\
\hline VENT VALVE & 1 & 2 & \multicolumn{3}{|c|}{ CPLG'6000 FULL THR. } \\
\hline DRAIN & 1 & $11 / 4$ & \multicolumn{3}{|c|}{ CPLG'6000 FULL THR. } \\
\hline MANOMETER & 1 & $1 / 4$ & \multicolumn{3}{|c|}{ CPLG'6000 FULL THR. } \\
\hline $\begin{array}{c}\text { TEMP. } \\
\text { INDICATOR }\end{array}$ & 1 & 1 & \multicolumn{3}{|c|}{ CPLG'6000 FULL THR. } \\
\hline $\begin{array}{l}\text { SAFETY } \\
\text { VALVE }\end{array}$ & 2 & 2 & \multicolumn{3}{|c|}{ CPLG'6000 FULL THR. } \\
\hline $\begin{array}{l}\text { ROTATING } \\
\text { GAUGE }\end{array}$ & 1 & 1 & \multicolumn{3}{|c|}{ CPLG'6000 FULL THR. } \\
\hline MANHOLE & 1 & 20 & \multicolumn{2}{|c|}{ W.N.R.F300 } & STD \\
\hline
\end{tabular}

Table 4: Material properties [16]

\begin{tabular}{|l|l|}
\hline Material Density & $7800 \mathrm{~kg} / \mathrm{m}^{3}$ \\
\hline Young's Modulus & $200 \mathrm{Gpa}$ \\
\hline Poisson's Ratio & 0.3 \\
\hline Bulk Modulus & $167 \mathrm{Gpa}$ \\
\hline Shear Modulus & $76.9 \mathrm{Gpa}$ \\
\hline
\end{tabular}

The required thicknesses for the cylindrical shell and the three head types are calculated according to ASME Div VIII Sec.1(UG-27) codes as given in table 5. [16] 
Table 5: Design thicknesses ASME (UG-27)

\begin{tabular}{|c|c|}
\hline Component & Design thickness formula \\
\hline Shell thickness & $t=\frac{P R_{O}}{S E+0.4 P}$ \\
\hline $\begin{array}{c}\text { Deep torispherical } \\
\text { heads }\end{array}$ & $t=\frac{P L_{O} M}{2 S E+P(M-0.2)}$ \\
\hline $\begin{array}{c}\text { Elliptical 2:1 heads } \\
\text { Hemi- spherical } \\
\text { heads }\end{array}$ & $t=\frac{P D_{O} K}{2 S E+2 P(K-0.1)}$ \\
\hline
\end{tabular}

According to the design data given in tables 2 and 4 , the calculated thicknesses of the three models are collected in table 6 .

Table 6: The required thicknesses as per ASME code

\begin{tabular}{|c|c|c|c|}
\hline Part & Model 1 & Model 2 & Model 3 \\
\hline $\begin{array}{c}\text { Cylinder shell } \\
\text { thickness (mm) }\end{array}$ & 14.27 & 14.28 & 14.28 \\
\hline $\begin{array}{c}\text { Head thickness } \\
\text { (mm) }\end{array}$ & 15.23 & 16.71 & 7.64 \\
\hline
\end{tabular}

The other parameters such as flanges, opining reinforcing areas, nozzles and saddle supports are calculated by using COMPRESS software. However the basic methods of calculations are given in the appendix.

\section{Finite Element Analysis}

Generally speaking it is difficult to derive a theoretical model to analysis the dynamical behavior for such complicated shape like pressure vessels with accessories and attaching components such as manhole, inlet and outlet supply, gauges, piping, supporting. Finite element method is the best way to analyze such structure by proper choosing of the building block elements and optimum meshing.

First of all, 3D solid models was created by using Solid Work 18. The dimensions of the three models are as per ASME. Hence three separated models were built to accomplish the three head types. Fig. 3 shows an example of solid model for Tori spherical head model.

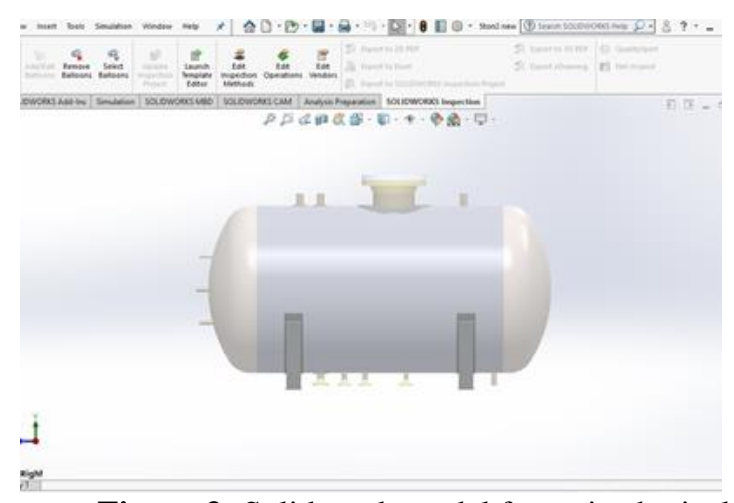

Figure 3: Solid work model for tori spherical heads vessel
Each model was exported to the ANSYS R18.2. The model was meshed using Body sizing meshing type in which the program optimize the best number of element introduced in the analysis as shown in fig. 4. Tetrahedral, solid 186 and solid 187 element types are selected for the vessel walls and the accessories. The basic shape, nodes and local coordinates for this elements are shown in fig. 5 [17].

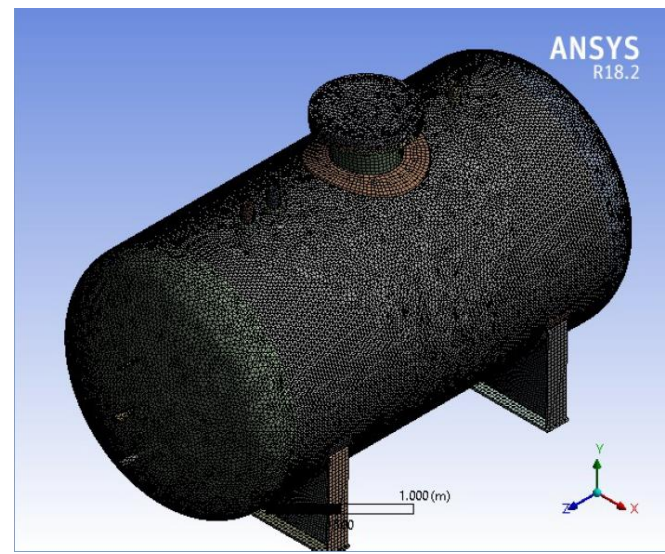

Figure 4: Meshing of the model

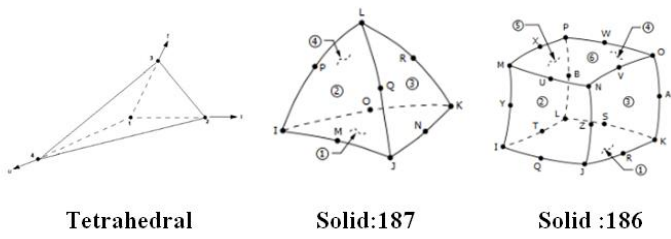

Figure 5: Element types used in the present analysis [17]

The main loding and boundary conditions are as the follow; the vessel is bulit in at the supports base in which all motions and rotations in three diretions $(\mathrm{x}, \mathrm{y}$ and $\mathrm{z})$ are set to zero. The loading is due to the internal pressure which is fluctuated from +18.0 to $18.0 \mathrm{~kg} / \mathrm{cm}^{3}$.

In order to analyzing fatigue a static analysis of stresses according Von Misses criteria is employed. For fatigue analysis the main concern are with fatigue life and fatigue failure location. In order to analyze fatigue it is assumed that the vessel can be subjected to fluctuating pressure due to the charging and discharging periods. The loading is assumed of constant amplitude with completely reversed cycle around zero mean as shown in figure 6-a. Figure 6-b shows the fatigue sensitivity for $50 \%$ to $150 \%$ of loading history. In the presented analysis a $100 \%$ loading history is selected.

For vibration analysis the main concerns are with the natural frequencies and mode shapes. Modal Analysis Method is used for evaluating the natural frequencies by using the spectrum analysis in term of Fourier transformation. 


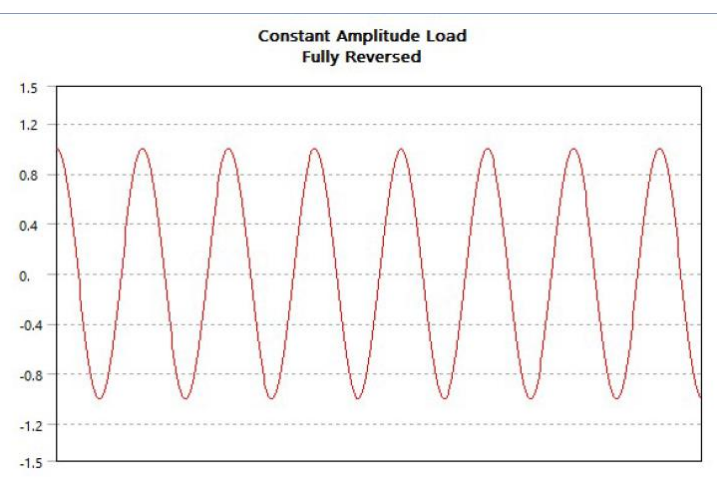

(a)

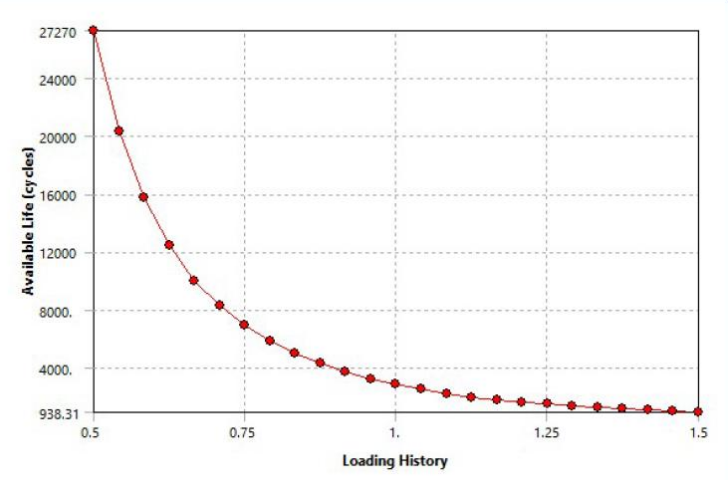

(b)

Figure 6 (a,b): Cycling stress due to pressure fluctuation and the fatigue loading sensitivity [18]

\section{Results and Discussions}

The results of fatigue life (in cycles) for the three models are collected in table 7. The locations of minimum and maximum fatigue failure are shown in fig. 7.

Table 7:Minimum and maximum fatigue life for models

\begin{tabular}{|c|c|c|}
\hline Model & Min.(cycles) & Max.(cycles) \\
\hline 1 & 2848.7 & $1 \times 10^{6}$ \\
\hline 2 & 2846.3 & $1 \times 10^{6}$ \\
\hline 3 & 2880.2 & $1 \times 10^{6}$ \\
\hline
\end{tabular}

As it can be seen from table 7; the worst case of fatigue life is observed at model 1 (i.e: for Deep torispherical heads) while the best is for Hemispherical heads model. Comparing the results show an increasing of about $180 \%$ in fatigue life. Inspections of figures 7 indicates that the failure initiates at the same location in all models while the maximum fatigue life has different locations in the vessels.

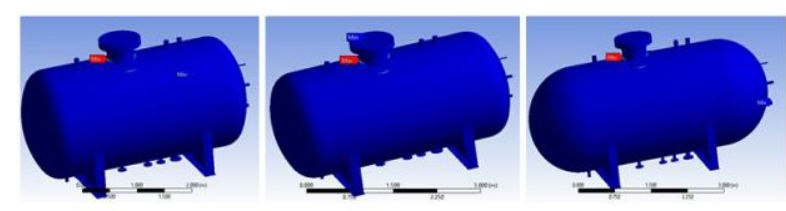

Figure 7: Locations of fatigue failure
For instant, the minimum value of fatigue life is more significant for failure since it refers to the initiation of damage.In fatigue analysis the safty factor is an impotant parameter to indicate design safty. It is found from fatigue analysis that the safty factor is identical for all models and it ranged from 2.19 to 5 as shown in fig. 8. Inspection the figure shows that the minimum safty are at the welding joints espitialy at the manhole.

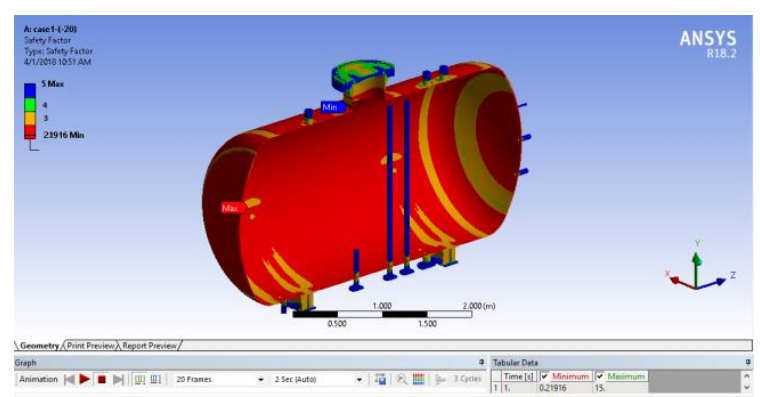

Figure 8: Fatigue safty factor

For vibration analysis case, the results of the lowest five modes of natural frequencies for the three models are given in table 8.A comparison between the three models indicates that the lowest four natural frequencies are nearly the same regardless the head type. On the contrary the fifth mode is significantly different and has minimum value for model 3 and maximum for model 2.(this behavior will be explained later).

Table 8: The lowest five natural frequencies $(\mathrm{Hz})$ the three models

\begin{tabular}{|c|l|l|l|}
\hline Mode No. & Model1 & Model 2 & Model 3 \\
\hline 1 & 11.478 & 11.456 & 11.450 \\
\hline 2 & 12.398 & 12.396 & 12.396 \\
\hline 3 & 12.463 & 12.460 & 12.460 \\
\hline 4 & 12.771 & 12.769 & 12.768 \\
\hline 5 & 32.551 & 50.773 & 29.150 \\
\hline
\end{tabular}

The mode shape deformations of five modes of model 1 are shown in figure 9. In order to show the detailed deformations due to vibration a half section is chosen. It is important to mansion that in such complicated structures it is difficult to distingush between the lateral, transverse and circufrantal modes of vibration due the the large number of degree of freedom so mixed modes are appeared. 


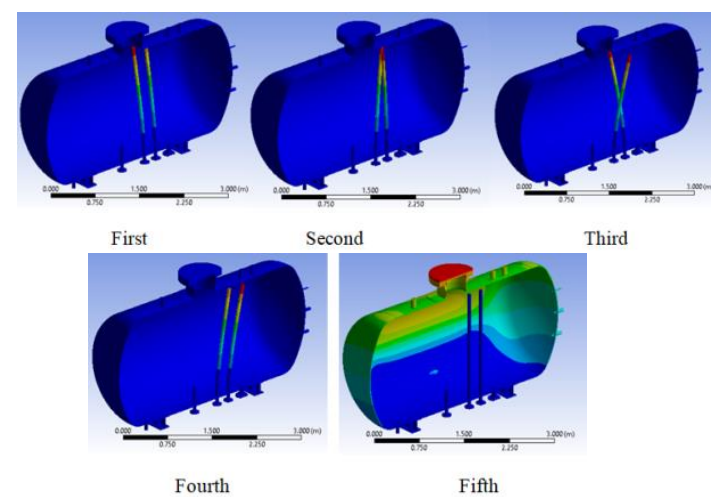

Figure 9: Vibration mode shapes of Deep torispherical vessel at half-section

As it can be obvious from the figures, the effect of vibration for the lowest four modes is not clear on the vessel body, It affects the internal components only such as internal pipes since they have the lowest stiffness. However when the natural frequncy increases at the fifth mode it alters the higher atiffness componants such as the vessel walls which are differents for the three models. This is the reason why the fifth natural frequency is highly related with vessel type since the structural stiffness is differed for the three models.

\section{Conclusions}

From the discussion of the results for fatigue and vibrations of the three models the following conclusions can be derived ;

1- Fatigue life (in cycles) can be increased as higher as $180 \%$ for hemi- spherical head as compared with deep torispherical head pressure vessel

2- The location of fatigue failure initiation is independent on the head types.

3- The lowest four natural frequencies are not affected by head types, However the fifth natural frequency is significantly altered. Elliptical head has the largest and hemi- spherical head has the smallest.

4- Although the choosing of head type is not critical in static design it can become significant for fatigue and vibration analysis.

\section{5- References}

[1] B.S.Thakkar, 2S.A.Thakkar (2013). DESIGN OF PRESSURE VESSEL USING ASME CODE,SECTION VIII, DIVISION 1. International Journal of Advanced Engineering Research and Studies, E-ISSN2249-8974

[2] Niyamat, M., \& Bicha, K. (2015). Design and Stress Analysis of Pressure Vessel By Using Ansys. International Journal of Engineering Sciences \& Research Technology. Retrieved from http:\%5Cnwww.ijesrt.com@

[3] Manish M. Utagikar1, Prof. S.B. Naik(2013). Finite Element Analysis of Obround Pressure
Vessels. International Journal of Modern Engineering Research (IJMER) www.ijmer.com Vol. 3, Issue. 5, Sep - Oct. 2013 pp-2717-2725 ISSN: 2249-6645

[4] Dhanaraj, A., \& Mallikarjuna, M. V. (2015). Design \& Stress Analysis of a Cylinder with Closed ends using ANSYS. Journal of Engineering Research and Applications Www.ijera.com.

[5] Kumar, V., \& Kumar, P. (2014). Mechanical design of pressure vessel by using PV-ELITE software

[6] Dubal, S. V., Gajjal, S. Y., \& Patil, V. G. (2014). Review on stresses in cylindrical pressure vessel and its design as per ASME code. IJETT, 11(6), 300-5.

[7] Narale, P., \& Kachare, P. S. (2012). Structural analysis of nozzle attachment on pressure vessel design. International Journal of Engineering Research and Applications (IJERA) ISSN, 22489622.

[8] Siva Sankara Raju R, D.Ashok (2013). Determination Of Stress And Deformations Analysis On Lpg Steel. Cylinder., International Journal of Engineering Research and Applications (IJERA) ISSN: 2248-9622 www.ijera.com

[9] Kulkarni, A. A., \& Jatkar, K. H. (2014). A review on optimization of finite element modelling for structural analysis of pressure vessel. IJETT, 12(1), 20-2.

[10] Lewiński, J. (2015). The effect of manhole shape and wall thickness on stress state in a cylindrical pressure vessel. Journal of Theoretical and Applied Mechanics, 53.

[11] Tamboli, K. (2014). Fatigue analysis of pressure vessel by FEA techniques. IJETT, 13(1), 25-8.

[12] Siva Sankara Raju R, D.Ashok, Thimothy Pandi. Determination Of Stress And Deformations Analysis On Lpg Steel Cylinder/ International Journal of Engineering Research and Applications (IJERA) ISSN: 2248-9622 www.ijera.com Vol. 3, Issue 1, January February 2013, pp.733-737 733 |P a g e

[13] Porter, M., Martens, D., \& McGuffie, S. (2006, January). Seismic Analysis of a Pressure Vessel. In ASME 2006 Pressure Vessels and Piping/ICPVT-11 Conference (pp. 337-344). American Society of Mechanical Engineers.

[14] Kumar, V., Kumar, N., Angra, S., \& Sharma, P. (2014). Design of Saddle Support for Horizontal Pressure Vessel. International Journal of Mechanical, Aerospace, Industrial, Mechatronic and Manufacturing Engineering, 8(12), 1-5.

[15] Mukhtar, F. M., \& Al-Gahtani, H. J. (2017). Design-Focused Stress Analysis of Cylindrical Pressure Vessels Intersected by Small-Diameter Nozzles. Journal of Pressure Vessel Technology, 139(2), 021205. 
[16]ASME, 2004, ASME Boiler and Pressure Vessel Code,Section VIII, Division 1, American Society of Mechanical Engineers, New York, NY.

[17] ANSYS release 18.2, 2018

\section{Appendix}

1- Saddle support design [16]
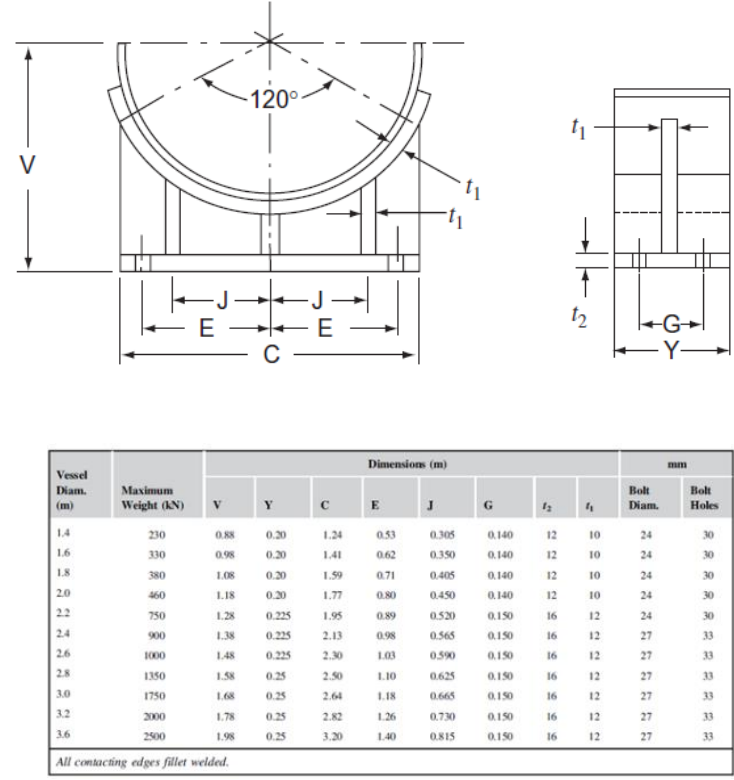

2- Nozzle design [16]
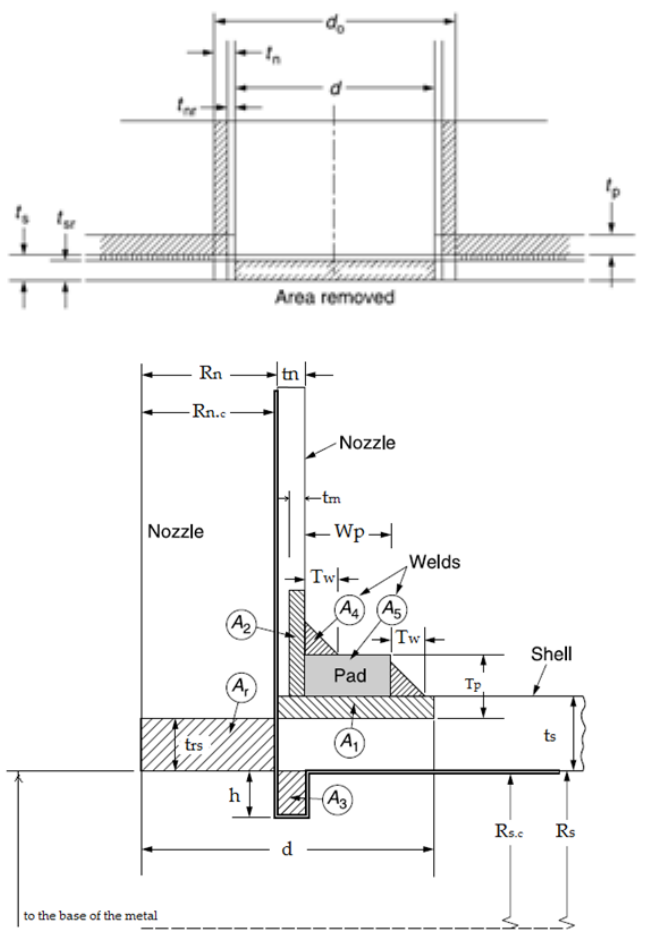

\title{
تأثير نوع نهايات رؤوس خزانات الضغط الأفقية لغاز البترول المسال على الاهتزاز

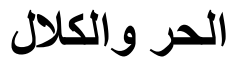

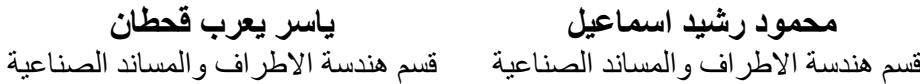 \\ جامعة النهرين \\ مروان عبدالرزاق سلمان \\ قسم الهندسة الميكانيكية \\ جامعة النهرين
}

الخلاصة

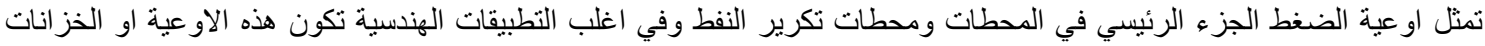

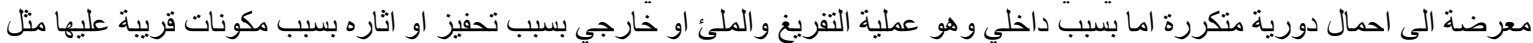

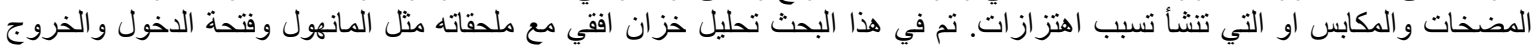

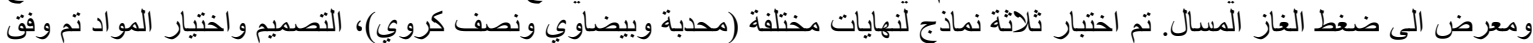

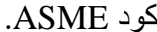

تم استخدام طريقة العناصر المحددة باستخدام برنامج الانسس 18 للتحليل العددي لتحديد عمر الكلال في حالة التحميل الدوري المعكوس الكامل

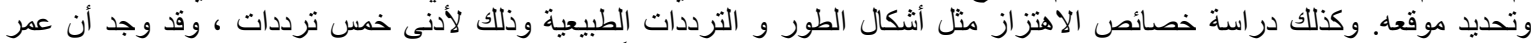

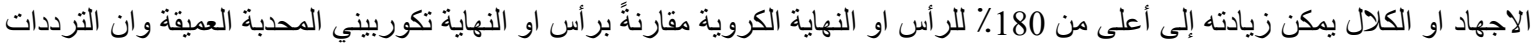

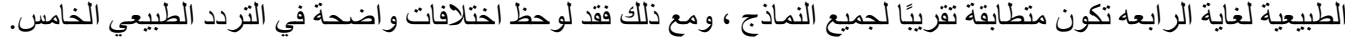

